\title{
Klinik örneklerden izole edilen anaerobik bakteriler: Yedi yıllık değerlendirme
}

\author{
Anaerobic bacteria isolated from clinical specimens: Seven-year review \\ Elif Bilge Uysal*, Cem Çelik, Çağlar Alan, Havva Kaya, Mustafa Gökhan Gözel, \\ Mustafa Zahir Bakıcı
}

Tıbbi Mikrobiyoloji Anabilim Dalı (Yrd. Doç. Dr. E. B. Uysal, Yrd. Doç. Dr. C. Çelik, Arş. Gör. Ç. Alan, Arş. Gör. H. Kaya, Prof. Dr. M. Z. Bakıcı), Enfeksiyon Hastalıkları Anabilim Dalı (Yrd. Doç. M. G. Gözel), Cumhuriyet Üniversitesi Tıp Fakültesi, TR-58140 Sivas

\section{Özet}

Amaç. Anaerob bakteriler önemli patolojilere neden olabilen bakteriler olmasına rağmen kültür ve izolasyonda yaşanan zorluklar nedeniyle sıklıkla gözden kaçmaktadırlar. Bu çalışmada 2006-2013 yılları arasında Cumhuriyet Üniversitesi Tıp Fakültesi Hastanesi Mikrobiyoloji Laboratuvarı'na, anaerob infeksiyon ön tanısı ile gönderilen örneklerden izole edilen anaerob bakterilerin, dağılımlarının incelenmesi amaçlanmıştır. Yöntem. Çalışmaya çeşitli kliniklerden anaeob bakterilerin üretimine uygun şekilde alınarak gönderilen 543 örnek dahil edilmiş, örnekler laboratuvar kayıtlarından geriye dönük olarak incelenmiştir. Bulgular. Çalışılan örneklerin 409'unda $(\% 75,3)$ üreme görülmezken, 134 örnekte $(\% 24,6)$ çeşitli anaerob bakteriler üretilmiştir. Çalışmamızda izole ettiğimiz anaerob bakteriler arasında da en fazla üreyen bakterinin Bacteroides spp. $(\% 29,9)$ olduğu görülürken, ikinci sırada Peptopstreptococcus spp. $(\% 23,1)$, üçüncü sırada Propionibacterium spp. $(\% 20,2)$ izole edilmiştir. Sonuç. Anaerob bakterilerin üretilmesi güç, zaman alıcı ve daha pahalı olmasına rağmen klinik örneklerden uygun şekilde alınıp gönderildiğinde önemli miktarda anaerob bakteri infeksiyon etkeni olarak izole edilebilmektedir. Anaerop bakterilerin klinik örneklerden tanımlanması ile anaerop etkenli enfeksiyonların daha isabetli bir şekilde tedavi edilebilmesine olanak sağlanacağı kanaatindeyiz. Çalışmamız sonucunda ortaya koyduğumuz yerel verilerin anaerob bakterilere bağlı infeksiyonların takip ve tedavisinde yarar sağlayarak bu konudaki literatüre katkı sunacağını düşünüyoruz.

Anahtar sözcükler: Anaerob bakteriler, anaerob infeksiyon, bacteroides spp

\begin{abstract}
Aim. Although anaerobic bacteria are a group of bacteria that can cause significant pathological changes, they are are frequently overlooked due to the difficulties in culturing and isolation. This study aims to investigate the distributions of anaerobic bacteria isolated from the specimens sent to the Microbiology Laboratory of the Cumhuriyet University School of Medicine between the years 2006-2013 based on a preliminary diagnosis of anaerobic infection. Methods. This study includes 543 samples properly collected from various clinics, these samples were retrospectively examined using laboratory records. Results. While there was no growth in 409 (75.3\%) of the study samples, various anaerobic bacteria were grown on 134 (24.6\%) samples. Our study found the highest growth rate $(29.9 \%)$ to be in Bacteroides spp. among the anaerobic bacteria isolated in our study, followed by Peptopstreptococcus spp. (23.1\%), and Propionibacterium spp. (20.2\%). Conclusions. As a result, although growing anaerobic bacteria is difficult, time-consuming and more expensive, it is possible to isolate a significant amount of anaerobic bacteria as infectious agents when clinical samples were properly collected and sent. We consider that describing anaerobic bacteria will allow for a more accurate treatment of such infections. We think that the local data obtained with this study will offer benefits in following and treating infections caused by anaerobic bacteria and contribute to the current literature.
\end{abstract}

Keywords: Anaerobic bacteria, anaerobic infection, bacteroides spp

Geliş tarihi/Received: 06 Haziran 2014; Kabul tarihi/Accepted: 18 Ağustos 2014

*İletişim adresi:

Dr. Elif Bilge Uysal, Tıbbi Mikrobiyoloji Anabilim Dalı, Cumhuriyet Üniversitesi Tıp Fakültesi, TR-58140 Sivas. E-posta: elifbilgeuysal@gmail.com 


\section{Giriş}

Anaerob bakteriler üreyebilmek için ortamdaki serbest oksijenin uzaklaştırılmasına gereksinim duyan, normal atmosferde veya \%5-10 karbondioksitli ortamda kat1 besiyerlerinde üreyemeyen bakterilerdir [1]. İnsan vücudunda anaerob bakteriler ağız boşluğu, gastrointestinal sistem, kadın genital organları ve cilt florasında bulunmaktadır. Anaerob infeksiyonların oluşmasında en önemli faktör, normal florada bulunan bu bakterilerin anatomik bütünlügün bozulması sonucunda, bulundukları bölgeden başka bölgelere özellikle de steril vücut bölgelerine geçmeleridir [2].

Anaerob bakteriler daha çok endojen yol ile bakteremi, beyin apsesi, karaciğer apsesi, peritonit, intraabdominal apse, yara infeksiyonları, jinekolojik infeksiyonlar, apendisit, pseudomembranoz kolit, osteomyelit septik artrit oluştururken, eksojen yol ile de gram pozitif sporlu basillerle infeksiyonlar meydana getirir [3, 4].

Anaerob bakteriler vücudun herhangi bir bölgesinde çok çeşitli infeksiyonlara neden olmakla beraber, bu infeksiyonlardan izole edilen türler sinırlı sayıdadır. Yapılan çalışmalar insandan alınan örneklerde üretilen anaerob bakterilerin çoğunluğunu Bacteroides başta olmak üzere Peptostreptococcus, Fusobacterium, Porphyromonas ve Prevotella türleri olduğunu göstermektedir [4].

$\mathrm{Bu}$ çalışmada 2006-2013 tarihleri arasında Cumhuriyet Üniversitesi Tıp Fakültesi Hastanesi Mikrobiyoloji Laboratuvarı'nda, anaerob infeksiyon ön tanısı ile gönderilen örneklerden izole edilen anaerob bakterilerin dağılımlarının incelenmesi amaçlanmıştır.

\section{Gereç ve yöntem}

Çalışmaya, Ocak 2006-Ocak 2013 tarihleri arasında Cumhuriyet Üniversitesi Tıp Fakültesi Hastanesi Mikrobiyoloji Laboratuvarı'na çeşitli kliniklerden anaerob kültür amacıyla, uygun şekilde alınarak gönderilen 543 örnek dahil edildi. Sürüntü şeklinde alınan numuneler reddedildi. Uygun taşıma besiyerine alınan veya enjektöre çekilerek havası alınmış şekilde laboratuvara gönderilen örnekler ise kabul edildi. Örnekler laboratuar kayıtlarından geriye dönük olarak incelendi. Hastaların aynı örneğine ait birden fazla kültür istemi olanlardan sadece biri çalışmaya dâhil edildi.

Anaerop kültür için, örnekler laboratuvara gelir gelmez, Schaedler agara, \%5 koyun kanı ve $\mathrm{K} 1 \mathrm{vitamini}(1 \mu \mathrm{g} / \mathrm{mL})$ eklenerek hazırlanan anaerop kanlı agara, aerop bakterilerin üretimi için de \%5'lik koyun kanlı agar (Salubris) ve EMB (eosin methylene blue) agar besiyerlerine ekildi. Ekim yapılan anaerob besiyerleri, anaerob kavanoza yerleştirilerek kuru sistem gaz paketi (AnaeroGen-Oxoid, Basingstoke, UK) ile oksijensiz ortam sağland1. Anaerob ortamın kontrolü için indikatör olarak anaerob indikatör (Oxoid, Basingstoke, UK) kullanıldı. Anaerop bakterileri üretebilmek için, besiyerleri anaerop ortamda $35-37^{\circ} \mathrm{C}$ 'de 48 saat inkübe edildi.

İnkübasyon sonunda anaerob besiyerlerinde üreyen her koloniden anaerob agar ve çukulata agara pasaj yapılarak bakterinin aerop ya da aerotoleran olup olmadığı kontrol edildi. Anaerob ortamda üreyip \%5-10 $\mathrm{CO}_{2}$ 'li ortamda çukulata agarda üremeyen bakteriler anaerob bakteri olarak değerlendirildi. Anaerob olarak üreyen farklı kolonilerden Gram boyama yapıldı ve preparatlar bakterinin boyanma özelliği ve spor oluşumu yönünden incelendi. İdentifikasyon için yarı otomatize bir sistem olan "BBL Crystal System" (BectonDickinson, USA) kullanıldı.

\section{Bulgular}

Mikrobiyoloji laboratuvarına gönderilen 543 örneğin dağılımı Tablo 1'de gösterilmiştir. Çalışılan örneklerin 409'unda $(\% 75,3)$ üreme görülmezken, 134 örnekte $(\% 24,6)$ çeşitli anaerob bakteriler üretilmiştir. 
Tablo 1. Anaerob infeksiyon ön tanısı ile gönderilen örneklerin dağılımı.

\begin{tabular}{|c|c|c|c|c|}
\hline Örnek & Sayı (\%) & $\begin{array}{l}\text { Tek başına } \\
\text { üreyen anaerop } \\
\text { bakteri sayısı }\end{array}$ & $\begin{array}{l}\text { Aerop bakterilerle } \\
\text { birlikte üreyen } \\
\text { anaerop bakteri sayısı }\end{array}$ & $\begin{array}{l}\text { Üreyen toplam } \\
\text { anaerob bakteri } \\
\text { sayısı }(\%)\end{array}$ \\
\hline Vücut sıvıları & $109(20,1)$ & 3 & 4 & $7(1,3)$ \\
\hline Plevra s1vis1 & 23 & 1 & - & 1 \\
\hline Perikard sıv1s1 & 9 & - & - & - \\
\hline Periton S1V1s1 & 36 & 2 & 4 & 6 \\
\hline Vitreus s1v1s1 & 31 & - & - & - \\
\hline BOS & 5 & - & - & - \\
\hline Eklem Sivisı & 5 & - & - & - \\
\hline Apse & $168(30,9)$ & 23 & 37 & $60(11,1)$ \\
\hline Yara* & $120(22,1)$ & 12 & 18 & $30(5,5)$ \\
\hline Kan & $5(0,9)$ & 1 & - & $1(0,2)$ \\
\hline Kemik ve yumuşak doku & $61(11,2)$ & 9 & 6 & $15(2,8)$ \\
\hline İntrakranial apse & $32(5,8)$ & 4 & 5 & $9(1,6)$ \\
\hline Kist sivis1 & $41(7,5)$ & 6 & 3 & $9(1,6)$ \\
\hline Kateter & $7(1,3)$ & 2 & 1 & $3(0,5)$ \\
\hline Toplam & 543 & $60(11,1)$ & $74(13,5)$ & $134(24,6)$ \\
\hline
\end{tabular}

Üreyen anaerob bakterilerden 60'1 tek başına ürerken, 74'ü beraberinde başka aerop bakterilerle üremiştir. Anaerob bakterilerle birlikte üreyen toplam 74 aerop bakterinin 34 tanesini gram pozitif bakteriler oluştururken, 40 'ını gram negatif bakteriler oluşturmuştur. Tanımlanan anaerob bakterilerin türlerine ve örnek tiplerine göre dağılımı Tablo 2'de verilmiştir.

Tablo 2. Tanımlanan bakterilerin türlerine ve vücut örneklerine göre dağılımı.

\begin{tabular}{|c|c|c|c|c|c|c|c|c|c|c|}
\hline Örnek & 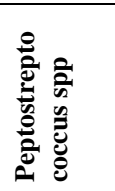 & 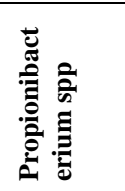 & 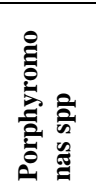 &  & 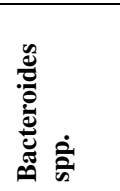 & है के & 窇 & 苍 & 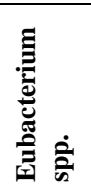 &  \\
\hline Vücut sıvıları & & & & & & & & & & $7(5,2)$ \\
\hline Plevra s1vis1 & & & & & 1 & & & & & 1 \\
\hline Perikard sıvısı & & & & & & & & & & \\
\hline Periton sivisı & & & & & 6 & & & & & 6 \\
\hline Vitreus sivis1 & & & & & & & & & & \\
\hline BOS & & & & & & & & & & \\
\hline Eklem sivisı & & & & & & & & & & \\
\hline Apse & 12 & 3 & 3 & 11 & 23 & 7 & & & 1 & $60(44,8)$ \\
\hline Yara* & 11 & 4 & 1 & 1 & 9 & 3 & 1 & & & $30(22,4)$ \\
\hline Kan & & & & & 1 & & & & & $1(0,7)$ \\
\hline $\begin{array}{l}\text { Kemik ve yumuşak } \\
\text { doku }\end{array}$ & 3 & 9 & & 2 & & & & 1 & & $15(11,2)$ \\
\hline İntrakranial apse & 2 & 4 & & 1 & & 2 & & & & $9(6,7)$ \\
\hline Kist sıvisı & 3 & 4 & & & & & 1 & 1 & & $9(6,7)$ \\
\hline Kateter & & 3 & & & & & & & & $3(2,3)$ \\
\hline Toplam (\%) & $31(23,1)$ & $27(20,2)$ & $4(2,9)$ & $15(11,2)$ & $40(29,9)$ & $12(8,9)$ & $2(1,5)$ & $2(1,5)$ & $1(0,8)$ & 134 \\
\hline
\end{tabular}

\section{Tartışma}

Anaeroblar, aerop bakterilerle beraber deri ve mukozaların normal bakteriyel florasinı oluştururlar. $\mathrm{Bu}$ bakterilerin doku hasarı sonucu steril vücut boşluklarına geçmesiyle anaerobik infeksiyon, aerop bakterilerin de infeksiyona dahil olması ile de polimikrobiyal infeksiyon meydana gelir. Ancak infeksiyona sebep olan bakteriler anaeroblar ise hem zor izole edilir, hem de sıklıkla gözden kaçarlar [5].

Hastanemiz mikrobiyoloji laboratuvarına çalışmamız tarihleri arasında anaerob infeksiyon ön tanısı ile gönderilen örneklerin çoğunluğundan hem aerop hem de anaerob etkenlerin beraber izole edildiği görülmüsstür (Tablo 1). Üreme saptanan 134 örneğin 74 'ünde hem aerop hem de anaerob bakteriler ürerken, 60 örnekten sadece anaerob 
bakteriler izole edilmiştir. Polimikrobiyal bakteri üreyen örneklere bakıldığında 40 örnekte gram negatif bakteriler, 34 örnekte de gram pozitif bakterilerin ürediği görülmüştür. Çeşitli çalışmalarda da çoğunlukla gram negatif bakterilerin, anaerob bakterilere eşlik ettiği görülmüştür [6,7].

Anaerob bakterilerin izole edildiği vücut örnekleri incelendiğinde; Durmaz ve ark. [8] 65 anaerob bakteri ürettiği çalışmada en fazla üremeyi apse örneklerinden elde ettiklerini bildirmişlerdir. Yine Ercis ve ark. [9] 217 anaerob üremenin 102'sini, Şengöz ve ark. [10] 127 anaerob üremenin 61'ni, Kiremitçi ve ark. [11] 33 anaerob üremeden 15'ini apse örneklerinden izole ettiklerini bildirmişlerdir. Bizim de çalışmamızda en fazla anaerob bakteri üretilen örnek grubu apse $(\% 44,8)$ örnekleridir.

Anaerob kültürlerden izole edilen bakteriler incelendiğinde en fazla Bacteroides türlerinin izole edildiği bildirilmektedir [8-11]. Çalışmamızda anaerob bakteriler arasında en fazla Bacteroides spp. (\%29,9)'nin izole edildiği görülürken, ikinci sırada \%23,1 oranında Peptopstreptococcus spp. üçüncü sırada \%20,2 oranında Propionibacterium spp. izole edilmiştir.

İntrakranial apse örneklerinden izole ettiğimiz anaerob bakteriler daha çok üst solunum yolları ve oral florada üreyen bakteriler olan Propionibacterium spp. $(n=4)$, Peptostreptococcus spp. $(n=2)$, Prevotella spp. $(n=2)$, Fusobacterium spp. $(n=1)$ 'dir. Moal ve ark. [12] ve Brook [13] kranial apseli çocuklardan aldığı örneklerde en fazla üreyen bakterilerin üst solunum yolları ve oral florada yer alan Prevotella spp., Fusobacterium spp., Actynomyces spp. ve Bacteroides türleri gibi anaeroblar olduğunu bildirmişlerdir. Özellikle oral florada yer alan anaerob bakterilerin çeşitliliğinden dolayı bu bölgeden üretilen bakteriler de çok farklı olabilmektedir.

Vücudun çeşitli bölgelerinden alınan yara örneklerinden en fazla tanımladığımız anaerob bakteri Peptostreptococcus spp. $(\mathrm{n}=11)$, Bacteroides spp. $(\mathrm{n}=9)$ ve Propionibacterium spp. $(\mathrm{n}=4)$ 'dir. Değişik çalışmalarda yara örneklerinin alındığ 1 yere bağlı olarak farklı bakterilerin ürediği görülmüştür. Bozkurt ve ark. [14] çalışmalarında laboratuvara gönderilen 10 yara örneğinin beşinde üreme saptamışlar ve üreyen anaerob bakterilerin Actynomyces israelii, Eubacterium rectale ve Propionibacterium acnes olduğunu bildirmişlerdir. Durmaz ve ark. [8] çalışmalarında 11 yara sürüntüsünün hiçbirinde anaerob bakteriye rastlamadıklarını bildirmişlerdir. Bahar ve ark. [15] 526 yara örneğini inceledikleri çalışmalarında, örneklerin \%41'inde anaerob bakteri saptamışlar ve en fazla üreyen anaerob bakterilerin Clostridium spp., Prevotella spp., Peptostreptococcus spp. ve Bacteroides spp. olduğunu ve bunların çoğunlukla cerrahi yara, dekübit yarası, diabetik ayak yarası örneklerinden izole edildiğini belirtmişlerdir. Bowler [16]'in 2001'de çeşitli araştırmacıların çalışmalarını ele aldığı yazısında ise, yaralardan en sık üretilen anaerobik bakterilerin Bacteroides spp. ve Peptostreptococcus spp. olduğu görülmüştür.

Peritoneal sıvı örneklerinden izole edilen anaerob bakteriler değerlendirildiğinde Brook ve ark. [17] 2000 yılında yaptıkları çalışmada 79 peritonitli hastadan elde edilen 110 örneğin 17'sinde Bacteroides spp. başta olmak üzere Peptostreptococcus sp.p, Clostridium spp., Fusobacterium spp. ve Prevotella spp. üretildiğini bildirmiştir. Mosdell ve ark. [18]'nın apendisit sonrası peritonit gelişen hastalarda yaptıkları çalışmalarında da en fazla Bacteroides fragilis'in ürediği görülmüştür. Çalışmamızda yukarıdaki çalışmalara benzer olarak peritoneal sıvı olarak laboratuvara gönderilen 36 örneğin altısında Bacteroides spp. ürediği görülmüştür.

Plevra sıvıları incelendiğinde, Bartlett ve ark. [19] 193 plevra örneğini inceledikleri araştırmalarında, çoğunlukla Peptostreptococcus spp., Bacteroides spp., Prevotella spp. ve Fusobacterium spp. ürettiklerini bildirmişlerdir. Bizim çalışmamızda ise 23 plevral örnek laboratuvara gönderilmiş, bunlardan birinde Bacteroides spp. üretilmiştir. Üretilen bakteri sayısı az olmasına rağmen hem plevral hem peritoneal örneklerde üretilen bakteriler diğer çalışmalarda üretilenlerle uyumludur. 
Sonuç olarak; anaerob bakterilerin üretilmesi güç, zaman alıcı ve daha pahalı olmasına rağmen klinik örneklerden uygun şekilde alınıp gönderildiğinde önemli miktarda anaerob bakterinin infeksiyon etkeni olarak izole edilebildiği görülmektedir. Antimikrobiyal duyarlılık testleri yapılmasa dahi bakteri tanımlamalarının yapılmasının bu tip infeksiyonların daha isabetli bir şekilde tedavi edilebilmesine olanak sağlayacağını, ayrıca çalışmamız sonucunda ortaya koyduğumuz lokal verilerin anaerob bakterilere bağlı infeksiyonların takip ve tedavisinde yarar sağlayarak bu konudaki literatüre katkıda bulunacağını düşünmekteyiz.

\section{Kaynaklar}

1. Torun MM. Anaerob bakteri infeksiyonları: Kültürde sorunlar, Klimik Derg 2003; 16: 25-8.

2. Görenek L. Anaerob bakteri infeksiyonlarında klinik sorunlar, Klimik Derg 2003; 16: $36-8$.

3. Ulusoy S, Leblecioğlu H. Önemli ve sorunlu anaerob bakteri infeksiyonlar1; Anaerob infeksiyonlar ve laboratuvar tanısı, Bilimsel Tip Yayınevi, Ankara 2005: 13.

4. Ustaçelebi Ş. Temel ve Klinik Mikrobiyoloji: Anaerob bakteriler, Güneş Tip Kitabevi, Ankara 1999: 612-5.

5. Naidoo S, Perovic O, Richards GA, Duse AG. Clinically significant anaerobic bacteria isolated from patients in a South African academic hospital: Antimicrobial susceptibility testing, S Afr Med J 2011; 101: 732-4.

6. Doğan M, Baysal B. Çeşitli klinik örneklerden izole edilen anaerob bakterilerin tanımlanması ve antibiyotik duyarlılıklarının belirlenmesi, Mikrobiyol Bült 2010; 44: 211-9.

7. Bennion RS, Baron EJ, Thompson JE, Downes J, Summanen P, Talan DA et al. The bacteriology of gangrenous and perforated appendicitis-revisited, Ann Surg 1990; 211: 165-71.

8. Durmaz B, Taştekin N. Anaerob infeksiyon ön tanılı hastaların klinik örneklerinden izole edilen anaerob bakteriler, Mikrobiyol Bült 1997; 31: 13-20.

9. Ercis $\mathrm{S}$, Tunçkanat F, Hasçelik G. Anaerobik infeksiyon şüpheli hastalardan izole edilen anaerob bakteriler, Mikrobiyol Bült 2005; 39: 447-54.

10. Şengöz G, Yaşar K, Berzeg D, Yıldırım F, Şengöz A, Elmi Ş ve ark. Klinik örneklerden izole edilen anaerob bakteriler ve antibiyotiklere duyarlıl1kları, Türk Mikrobiyol Cem Derg 2005; 35: 107-13.

11. Kiremitçi A, Türkkan AA, Akgün Y, Durmaz G, Kaşifoğlu N. Klinik örneklerden anaerob bakterilerin soyutlanması ve antibiyotik duyarlıl1klarının belirlenmesi, Ankem Derg 2008; 22: 132-44.

12. Le Moal G, Landron C, Grollier G, Bataille B, Roblot F, Nassans P et al. Characteristics of brain abscess with isolation of anaerobic bacteria, Scand $\mathbf{J}$ Infect Dis 2003; 35: 318-21.

13. Brook I. Aeropic and anaerobic bacteriology of intracranial abscesses. Pediatr Neurol 1992; 8: 210-4.

14. Bozkurt H, Güdücüoğlu H, Bayram Y, Gülmez S, Kutulay N, Bozkurt EN ve ark. Klinik örneklerden izole edilen anaerob bakteriler ve antibiyotik duyarlılıkları, Van Tip Derg 2004; 11: 85-91.

15. Bahar H, Torun MM, Demirci M, Sever N, İstanbullu A. Yara infeksiyonlarında anaerob bakterilerin dağılımı, Türk Mikrobiyol Cem Derg 2003; 33: 42-6.

16. Bowler PG, Duerden BI, Armstrong DG. Wound microbiology and associated approaches to wound management. Clin Microbiol Rev 2001; 14: 244-69.

17. Brook I, Frazier H. Aerobic and anerobic microbiology in intra-abdominal infections associated with diverticulitis, J Med Microbiol 2000; 49: 827-30.

18. Mosdell DM, Morris DM, Fry DE. Peritoneal cultures and antibiotic therapy in pediatric perforated appendicitis. Am J Surg 1994; 167: 313-6.

19. Bartlett JG. Anaerobic bacterial infections of the lung and pleural space: Clin Infect Dis 1993; 16: 248-55. 